\title{
ENVIRONMENTAL POLICY IN THE PROGRAMS OF POLITICAL PARTIES IN MACEDONIA
}

\author{
Svetlana Veljanovska \\ Faculty of Law Kicevo - UKLO Bitola, North Macedonia \\ svetlana.veljanoska@uklo.edu.mk
}

Professional Paper

10.5937/jouproman9-30168

\begin{abstract}
This paper aims to analyze whether, how much and in what way environmental policies are developed in the programs of political parties in Macedonia. The paper will initially develop the terms party, party program and policies in the field of ecology.
\end{abstract}

The central topic of the paper is the environmental policy in the programs of the parties and their systematization in terms of the topics on which they base their policies.

The author will try to contribute to the typology of parties in terms of their attitude towards environmental issues.

Keywords: party, parties program, environmental policy.

\section{INTRODUCTION}

Parties, in addition to other content on their program platform, should have an environmental policy. Therefore, this paper aims to acquaint us with the attitudes of the parties towards the environment, what problems they locate in society and to show us what their answers to them are.

The fact is that the parties differ in their views on political, economic and even environmental issues. Therefore, in this paper we present these differences and find possible similarities through the analysis of party programs and public policy proposals.

\section{DEFINING TERMS IMPORTANT FOR WORK}

Political parties are organizations that mediate between citizens, civil society and the state. A political party is a voluntary organization of citizens, established to exercise and protect political, economic, social, cultural and other rights and beliefs in order to participate in the political decision-making process during participation in the Government. Political parties achieve their goals through democratic formation and expression of political will, participation in elections, as well as in other democratic ways. ${ }^{1}$

There is no party without at least a minimal form of a developed political and ideological project around which members and supporters would gather and integrate. In line with this definition of political parties, we can also bring ecology into the debate. The attitude towards environmental issues and problems can be an element of a political and ideological project around which party members gather.

\footnotetext{
${ }^{1}$ LAW ON POLITICAL PARTIES S1. Journal of the Republic of Macedonia no. 76/2004 of 27.10.2004
} 
Of course, without some in-depth research and review of political parties and the party scene in Macedonia, we can conclude that so far there is no such strong identification with parties based on environmental issues (with the exception of DOM as a party declared a Green Party in Macedonia).

Therefore, it is necessary to analyze the party's programs. The program of a political party contains provisions on the goals and choice of the form and manner of operation of a political party (Article 15 of the LCP). But more important for this work is that the party's program is a set of ideas and principles on which the party bases its political project, recognizing social problems and possible ways to solve them. Party programs, however, are a set of strategic goals, ideas, values and commitments (Goati, 2005: 10). ${ }^{2}$

From these two definitions, we see that these are documents that the parties present in order to seek the support of voters in the elections. In the party programs, they put all the important questions for the society and the political system, so that they find their place here and the ecological topics that are the subject of this paper.

Environmental problems are increasingly emerging in a globalized society and the Government must address them through public policies. Political parties are subjects of environmental policy and therefore this paper refers precisely to their impact on ecology and environmental policy.

${ }^{2}$ Goati, V. (2005), "Party program as a key element of party identity", in: Mihailović, Srećko (ed.), Program identities of social democratic parties, Belgrade: SDK and FES, p. 9 - 28.

\section{ENVIRONMENTAL POLICY}

The emergence of elements of environmental policy in party programs is related to the development of human rights. As Kani (2009: 227) says: "There is no longer any doubt that human activity leads to a serious and accelerated deterioration of the Earth's climate, and consequently the concept of four basic human rights is developing: life, health, survival and forced relocation. "All four of these rights are directly correlated with environmental issues, and the key thing to say is that environmental issues threaten the entire corps of first, second and third generation human rights." 3

Environmental protection policy is a conscious and organized socially oriented activity that, through the state and social, especially political organizations, directs the attitude of society towards nature for the protection and improvement of the environment.

For further analysis, it is necessary to define the term sustainable development, because it is often the topic of party programs. The best definition of sustainable development is the one from the book Our Common Future, created as a report of the World Commission on Environment and Development in 1987. According to that definition, sustainable development is development that meets the needs of the present without compromising the ability of future generations to meet their own needs. ${ }^{4}$

\footnotetext{
3 See in detail in: Caney, S. (2009), "Human Rights, Responsibilities, and Climate Change," in: Beitz, C; Goodin, R. (eds), Global Basic Rights, Oxford: Oxford University Press, pp. 227 - 247.

${ }^{4}$ Nadić, D. (2011), "Sustainable development and principles of sustainable development in strategic documents of the Republic of Serbia", in: Vujačić, Ilija (ed.), FPN Godišnjak 2011, Vol.5; No. 6, Belgrade: FPN, p. 213 - 224.
} 


\section{ENVIRONMENTAL POLICIES IN THE RELEVANT PARTIES IN MACEDONIA IN 2020}

\subsection{Democratic Renewal of Macedonia $(\mathrm{DOM})^{5}$}

Although not one of the main parties on the political scene in Macedonia, the Democratic Renewal of Macedonia (hereinafter DOM) is still considered to base its platform on a project to respect human rights and freedoms in the field of environment or as stated in their program green priorities. These are environmental protection, sustainable urban development, a green economy that does not pollute the environment with green jobs, renewable energy sources and energy efficiency, ecotourism, eco-agriculture and healthy food, waste and water management.

According to the program commitments, no pressure can distract them from the green ideology, because in parallel with the processes of democratization in Macedonia and the creation of a functional democratic state, conditions for a humane life in a healthy environment must be created.

Among other goals, DOM is committed to harmonizing the goals of reducing greenhouse gases with the goals of the European Union. Namely, in the document with "national contributions" R. Macedonia aims to reduce greenhouse gases by $30 \%$ by 2030 , while the European Union wants to reduce them by $40 \%$ by 2030. Given the fact that all policies, including environmental, are related to financial resources, the DOM is committed

5

https://www.dom.org.mk/pdf/DOM\%20Programa $\% 202016 \% 20-\% 20 v 03 . p d f$ to creating a Climate Change Fund, which will be managed by the Ministry of Environment and Physical Planning. The fund should have a mechanism that will receive funds in order to invest in the development of a low-carbon economy, i.e. the development of renewable energy sources and increased energy efficiency measures.

\subsection{Social Democratic Alliance of Macedonia (SDSM) ${ }^{6}$}

Clean air and a healthy environment are SDSM's top priorities. By a joint, coordinated action, all institutions are taking daily measures to overcome the decade-long problem with pollution in order to reduce pollution by 50 percent in Skopje and by 30 to 50 percent in the whole of Macedonia in the next two years. The SDSM-led government and all relevant institutions are taking a number of measures at the local and national levels to address the long-standing problem of air pollution. Vegetation that has been systematically destroyed is being restored. In Skopje, Bitola, Veles and other places across the country, measures are being taken for landscaping, trees are being planted and greenery is being restored. Landfills are being intensively cleaned, inspections are more frequent, and nonecological energy sources are being replaced in schools. Gasification activities have been intensified, and subsidies for ecological pellet stoves for heating houses are underway. Problems with all sources of pollution have been solved.

\footnotetext{
6

https://mojotizbor.mk/images/programi2020/Progra ma-2020_Mozeme.pdf
} 
From next year, 40 new ecological buses will be procured for the city of Skopje, and the procurement is planned in other cities such as Bitola and Prilep. These are just some of the environmental policies and measures that are continuously taken to solve the decades-long problem of pollution.

The SDSM-led government has decided to subsidize citizens for the purchase of ecological inverter air conditioners for households that heat with non-ecological energy sources and devices. 10,000 households from Bitola, Kicevo, Tetovo and the city of Skopje received the opportunity for a subsidy of 1,000 euros for the purchase of inverter air conditioners.

The environmental policy in the program of the political party SDSM can be seen in the projects of building regional waste management centers in three regions. As well as the construction of wastewater treatment plants in all settlements with over 30,000 inhabitants.

\subsection{VMRO - Democratic Party for Macedonian National Unity (VMRO- DPMNE) ${ }^{7}$}

This party, referring to the data of the WHO on the consequences of air pollution, inadequate waste treatment and water pollution, promotes the so-called An agreement for a healthy and clean environment in which the priorities are: clean air, proper waste treatment, clean water and rivers, the fight against urban noise, greening of Macedonian cities and

\footnotetext{
7

https://mojotizbor.mk/images/programi2020/Progra ma-2020_Mozeme.pdf
}

mountains, urban planning for people and climate change.

They announce substantial changes in the regulation of the weakest links in the system, such as: environmental inspections that either do not have competencies, do not have the knowledge, do not have the means or do not have the will to act against pollutants.

They consider it necessary to establish a central inspection body with responsibilities at all levels related to environmental pollution and waste. This setting of the Environmental Inspectorate will enable: strict and fair inspection of environmental pollutants.

The program of the VMRO-DMPNE party announces that it will work on reducing the emission of solid particles from households after the Program - My home does not pollute. Waste management is a question that directly affects whether our environment is clean, what is flammable, what emissions are into the air as a result of combustion and what are the effects of waste in water and soil.

\subsection{Democratic Union of Albanians (DUI) ${ }^{8}$}

This is a party that has been participating in the ruling coalition in the country for many years. In their party program, topics that develop environmental policies are divided into several chapters, such as transport, safe energy, energy efficiency, renewable energy, and some of them are covered in the chapter on agriculture.

\footnotetext{
${ }^{8}$ https://mojotizbor.mk/images/programi2020/BDIPROGRAMA-2020-.pdf
} 
In the field of energy efficiency and renewable energy, DUI policies are aimed at gasification of the country and increasing the capacity of renewable sources, and in agriculture the concept is focused on maximum use of food production areas that would be sold on markets in the country but also for export. They also have a concept for increasing production capacities for processing agricultural products and for their modernization.

\subsection{Voice for Macedonia9}

This political party has an entire chapter dedicated to ecology in its election program. Measures for cleaner air in terms of transport, street hygiene in settlements, encouraging the use of vehicles that do not pollute the environment, energy efficiency of residential buildings, establishing a system for monitoring air pollution in cities and other measures have been elaborated in detail. Due to the fact that this party is not part of the governing structures in the country, its environmental policies are difficult to achieve.

\subsection{INTEGRA - Macedonian Conservative Party ${ }^{10}$}

This party is new on the Macedonian political scene and as such has an extensive program in the field of environmental policies. As it is now, it has a vision to build a society that will enable the systematic production of healthy, happy and satisfied citizens, who will live in harmony with nature and in the conditions of the highest degree of environmental protection.

\footnotetext{
${ }^{9}$ https://mojotizbor.mk/images/programi2020/glasza-makedonija.pdf 10

https://mojotizbor.mk/images/programi2020/INTE GRA-2020.pdf
}

In order to achieve this development vision for the state of Macedonia, the environmental management system will have to be reformed and conditions created so that its vital resources are not endangered. The plans are systematized in parts: development of green economy, administrative capacities in the environment, water management, waste management reforms, control of air pollution, reduction of pollution from industry, etc.

\subsection{Left $^{11}$}

This is also a new party on the political scene in Macedonia, but it has its representatives in the Parliament, so that their views can be heard, among other things, on the environmental policy in the country. The part of their program that is intended for environmental policy issues is called Green Policy and the greatest emphasis is placed on gasification in the country as soon as possible. Sustainable projects and the establishment of a public company to supply all state, municipal and public institutions with electricity produced in Macedonia. Other aspects of environmental policies, such as healthy food production, are included in the section on agriculture.

\subsection{Democratic Party of Albanians (DPA) $)^{12}$}

According to this party, one of the guaranteed constitutional rights of citizens is the right to a healthy environment.

\footnotetext{
11

https://mojotizbor.mk/images/programi2020/Levica -programa-A4-final-za-net-12.06.2020-1.pdf

https://mojotizbor.mk/images/programi2020/Platfor ma-PDSH-2020-2024.pdf
} 
But unfortunately modernization, technological development, climate change and similar phenomena are only part of the negative human impact on the environment.

Therefore, within the activities of the community, they emphasize that they are constantly committed to the rational use of natural resources in order to provide conditions for the sustainable development of the environment of citizens and a healthy environment.

Some of the goals they want to achieve are: Protection and improvement of the environment by achieving the goals set by approved spatial strategies and plans, integration of environmental policies and spatial planning into other sectoral policies for sustainable planning and use of space and resources, achieving European environmental quality standards, nature and sustainable development through the implementation of legislation in this area, the provision of environmental information and access to public information, public participation in environmental decision-making and active participation in international environmental protection systems.

Part of their efforts is to raise public awareness and educate the public about environmental rights and obligations, as well as to develop institutional and administrative capacity in this area.

DPA has not forgotten the concept of approximation of national legislation to the legislation of the European Union and the use of funds from European funds.

\section{TYPOLOGY OF POLITICAL PARTIES RELATED TO ENVIRONMENTAL ISSUES}

At the end of the analysis of the programs of relevant political parties on the topic of ecology, we will try to synthesize what has been said and observed so far in some kind of typology.

Environmentalists, the Greens, will be our ideal model, and based on that, we will define the parties as ecologically healthy, ecologically aware, ecologically participatory and non-ecological parties.

A. Ecologically mature parties are parties that arose from the idea of environmental protection and post-materialist values. Using the program principles of the European Federation of Green Parties in the European Parliament, it can be said that these are parties that strive for social and environmentally sustainable development. They believe that it is necessary to achieve ecological stability and balance, so that the four pillars in defining green policies: ecology, social rights, fundamental democracy and nonviolence are their working principles. It is clear that only the Democratic Renewal for Macedonia - DOM, belongs here.

B. Environmentally conscious parties are those parties that are not founded and their main principle of existence is not ecology, but they are aware of the environmental problems faced by the modern state and pay special attention to these issues in their programs. Based on the previous analysis, we conclude that the pro-environmental parties in Macedonia are: SDSM, VMRO DPMNE, Voice for Macedonija and DPA 
3) Ecologically participatory parties are parties that dedicate part of their program to this topic, but are not that much active, do not present these topics to their voters and are not particularly interested in them. The parties that belong to this group are: DUI, INTEGRA - Macedonian Conservative Party and Left

4) Non-environmental parties are parties that do not have elements in their programs that touch on environmental protection policies, parties that do not even mention these topics in their election and other campaigns. We do not have such case, at least in the analysis presented.

This typology shows that there is absolutely no correlation between the party ideology and the issues of ecology and environmental policy.

In the world, mostly social democratic parties are committed to environmental issues, but in Macedonia it can be concluded that almost all parties are concerned about this issue (at least declaratively), regardless of whether they are left, right or belong to the center.

\section{CONCLUSION}

The paper analyzes the programs of political parties on the topic of environmental policy. At first glance, it is clear that the programs are very similar. In some programs, some of these issues are elaborated in more detail, and some of them represent environmental policy in several different chapters. Of course, the problem is that when the parties gain power (become part of the ruling coalition in the country), they often forget about their promises.

The key thing is that citizens do not deal with environmental issues and do not set environmental requirements for parties and the state. Ecology is not the basis of political mobilization in Macedonia, except perhaps to some extent the DOM, but the support of citizens for this party is negligible.

Of course, there are reasons for all that, which are primarily seen in the unresolved issues of the political community in terms of economic and existential problems of citizens. The transition from respecting the materialist to advocating for postmaterialist values requires certain preconditions that are difficult to express, at least for now in Macedonia. Unfortunately, it must become clear that environmental problems cannot wait indefinitely to be solved!

\section{REFERENCES}

- Caney, S. (2009), "Human Rights, Responsibilities, and Climate Change", in: Beitz, $\mathrm{C}$

- Marković, D. (2005), Social Ecology, Belgrade: Institute for Textbooks and Teaching Aids.

- Nadić, D. (2004), Green Parties in Europe, Belgrade.

- Orlović, S. (2007), "Ideologies and Programs in Party Confrontations", in: Lutovac, Zoran

- Paterson, M; Doran, P.; Berry, J (2006), Green Theory, in: Hay, C; Lister, M. and Marsh, D.

(eds), The State: Theories and Issues, New York: Palgrave Macmillan, pp. 135 - 154.

- Stojiljković, Z. (2011b), "Political Families in the European Parliament”, in: Stojiljković, Z;

- Pilipović, G. (ed.) Political groups in Europe, Belgrade: KAS, p. 101 - 251.

\section{Documents and programs:}

- Project "Renewal of Macedonia" 2020 VMRO DPMNE

- DOM program "Voice for Macedonia" 2020

- SDSM program "We can" 2020

- DUI -Program 2020

- DPA -Platform for the period 2020-2024

- Integra -election platform 2020

- Left hand - election platform 2020 